\title{
SQUATTING OUTSIDE THE WORLD: NOTES FOR AN ARCHITECTURE OF ETHICS
}

\author{
Steven SCHROEDER \\ Graham School of Continuing Liberal and Professional Studies, \\ University of Chicago, Chicago, USA \\ E-mail: schroeder@uchicago.edu
}

Received 08 April 2014; accepted 05 September 2014

\begin{abstract}
Mind takes place in the world, and that matters. We are bodies among bodies, and, no matter what we think, what we do is a matter of where. And thinking about where is a problem for architecture. Richard Luecke's pithy summary of Aristotle's Politics was that we go to the city to live but stay to live the good life. The interplay of going and staying takes up a critical theme of Aristotle's work. To understand the world, he said, we must understand both motion and stasis - not the going alone but the staying that takes place in the middle of it. Luecke took up William James's figure of perchings in the flight of a bird and put it to work in thinking about cities. The city is a perch for the winged thing we are. To understand our flight, we must also attend to our perching. Aristotle speaks of the city as a place to go and a place to stay, but he also speaks of it as a koinonia turned toward good. That marks it as being human. Aristotle directs our attention to the necessity of the city (we go to live) and to its good (we stay to live the good life). But the staying, the dwelling, is understood within a structure of action: the good is that toward which all things aim. Dwelling, still, we turn. Which qualifies the going, because we are political animals. Going to the city to live, we go nowhere other than where we are. The city is the form of human presence.
\end{abstract}

Keywords: place, Aristotle, Marx, city, human presence.

Aber der Mensch, das ist kein abstraktes, außer der Welt hockendes Wesen. Der Mensch, das ist die Welt des Menschen, Staat, Sozietät. Dieser Staat, diese Sozietät produzieren die Religion, ein verkehrtes Weltbewußtsein, weil sie eine verkehrte Welt sind. Die Religion ist die allgemeine Theorie dieser Welt, ihr enzyklopädisches Kompendium, ihre Logik in populärer Form, ihr spiritualistischer Point-d honneur, ihr Enthusiasmus, ihre moralische Sanktion, ihre feierliche Ergänzung, ihr allgemeiner Trost- und Rechtfertigungsgrund. Sie ist die phantastische Verwirklichung des menschlichen Wesens, weil das menschliche Wesen keine wahre Wirklichkeit besitzt. Der Kampf gegen die Religion ist also mittelbar der Kampfgegen jene Welt, deren geistiges Aroma die Religion ist (Marx 2007).

Marx had Hegel in mind when he went to work on the work of religion, which he saw as being architectonic in the way Aristotle seems to have seen politics being.
It is no wonder he devoted considerable time to outing him - out of his mind into the world, with good reason. He was, you know, there already: a particular mind is no place for a maker of general theories. There is no place for a mind to be but in the world, where the theory and its maker must be as well. Marx turned his attention (and called the attention of anyone within earshot who might be inclined to listen) to the absurdity of making mansions (to borrow an image from Kierkegaard), then squatting in gatehouses when it is time to move in, being on edge after making a scene thinking oneself outside.

It is not the posture but the appearance of abstract being outside the world that catches his eye and inspires his critical judgement. In the act, he says, in the world acting. Which calls our attention not only to the world acting but - more specifically - to the world acting in the presence of humanity. 
In the presence - the presencing - of humanity, the location, the direction, and the state of human being in the world. In a manner of speaking, it turns on an architecture.

We begin as embodied beings with a capacity for language.

As embodied beings, we possess a capacity to transform the world. More exactly, we cannot not transform the world. By being in the world, we make an object of it and being in it. We make the world a world of objects.

That we are beings with a capacity for language is an aspect of our propensity to exchange. We can not not exchange: if we were closed to the world entirely, we would simply cease to be. We may fancy ourselves unique in this, but it is a common feature of organism. It is what an organism is, because it is what an organism does.

Among the things that we exchange are the objects that result from our acting in (and on) the world - but also (as Adam Smith notes) the capacity to objectify i.e. our labor (Smith 1976).

Value is a product of our objectification of the world. As Smith would have it, wealth derives from ownership of labor, which is the only source of value.

As embodied beings, we take place - we occupy space. Owning our labor, we stake a claim to the space we occupy: we come to be concrete beings squatting, in a manner of speaking, in the world. Taking place, we think we have bodies that occupy space. The object, we think, is to occupy space. That calls our attention to the architecture of the spaces we occupy: we are preoccupied with architecture.

When Marx thinks religion, he smells a rat - and therein lies a critical hint of the particular state of human being in the world. A general theory of the world rises out of practice in beings with a propensity to language. It is the aroma of human being in a place, and it is one of the most reliable ways to get a taste of the place. The taste of the place, in turn, is a reliable indicator of where desire there will turn. And that to which desire turns is what is thought to be good.

Not, mind you, what is good, but what is thought to be good. And this brings us to the heart of the problem for ethics. When we speak of the good we seek (as we do when we do ethics), we speak as though we think we speak of the good. But if we speak of what we seek, we speak of what we think is good: the object of our language is a thought that depends on a "we," an abstraction of an abstraction. Making a scene, we are tempted to think ourselves outside; we are tempted to the gatehouse.

What we take to be concrete action turns on turning toward an abstraction from an abstraction, and so the we and that which it thinks good turn us. The focus of ethics is not an I acting but the we in which I act and that which it thinks good. The I, the we, and that which it thinks good are all products of thought and language. We might say in the beginning is the act; but in the act of saying we turn to word. It is a world of words to the end of it (Goethe 1997; Stevens 2011).

We are not beings who possess a capacity for language, but beings who live in language - creatures whose being takes place in language. Not in the beginning was the word or in the beginning was the act but being always in the act in the middle of a world of words. Now. What do we make of this? What do we mean by this "we" we say is making? And what is the "this" of which we say we make (making that here now in the process, which will become this there then for an other)?

Dwelling on thought and language, we space out. Mind takes place in the world, and that matters. We are bodies among bodies, and, no matter what we think, what we do is a matter of where. And thinking about where is a problem for architecture (Taussig 1993).

Richard Luecke's pithy summary of Aristotle's Politics was that we go to the city to live but stay to live the good life. The interplay of going and staying takes up a critical theme of Aristotle's work that distills the critical conversation for which we remember classical Greek thinking and gives it a way into the future - including our present. To understand the world, he said, with an eye on Herakleitos and Parmenides, we must understand both motion or change and stasis - not the going alone but the staying that takes place in the middle of it. Luecke took up William James's figure of perchings in the flight of a bird (which James used to illustrate the way the mind works) and put it to work in thinking about cities. The city, we might say, is a perch for the winged thing we are. To understand our flight, we must also attend to our perching. More importantly, successful flight needs places to light (Luecke 1972; Aristotle 1932; James 1918).

Aristotle speaks of the city as a place to go and a place to stay, but he also speaks of it as a koinonia turned toward good. That marks it as being human. Aristotle directs our attention to the necessity of the city (we go to live) and to its good (we stay to live the good life). But the staying, the dwelling, is understood within a structure of action: the good is that toward which all things aim. Dwelling, still, we turn.

Which qualifies the going, because we are political animals. Going to the city to live, we go nowhere other than where we are.

The city is the form of human presence. It is (to borrow an image from Miller Williams) the human shaped hole we make in the grass circling the way a dog circles to get comfortable (Williams 1999). 
We make a disastrous mistake when we separate "city" from "country." Wherever there is human presence - even passing through (as I suspect we always are), there is city. The visible city is the human interface with (the rest of) the world.

And that is why, in Aristotle's terms, politics is an architectonic science - not because it is an externally imposed constraint on human behavior but because it is the shape human being takes in the world. The polis is the human shaped hole we make in the grass when we settle into comfort (and anyone who has given Aristotle even a passing glance knows that "we" implies "they" and that "our" getting comfortable often makes "them" uncomfortable). Politics is the settling that makes the polis. Ethics is a language of means and ends, a language of limits, within that science: the good is that at which all things aim (ends), but the practical question is what is needed to get there (means) (Deng Xiaoping's theory of cats comes to mind: it doesn't matter if it's a black cat or a white cat. If it catches a mouse, it's a good cat. But Chairman Deng neglected to mention that mice, too, stay in the city to live a good life - which complicates the question of the good cat in ways that matter for builders of cities).

We do not possess a capacity for language. We live in language. Language is where we are at home if we are at home at all, and that is critical if "our" city is to do more than crush the local grass until "we" move elsewhere to make ourselves at home again.

This poses two central questions that we might take as guiding principles for the design of cities: how do we welcome strangers? and how do we behave as guests? The questions are two sides of one coin; and they make the central concern for city planning not resilience (though that is likely to be a side effect) but hospitality. For concrete beings squatting in the world, this is a central concern.

Fresh in my mind as I write this is a conversation with a friend that circulated around our different experiences of the midwestern United States (which, as Bob Dylan reminds me, is - by the usual definition - the city I come from) and her description of New York City as "sparkling." I have no doubt that New York City sparkles (though I am acquainted with many people who would not use that term to describe the city). And it is certainly a leading candidate for the title of paradigmatic 20th century city of light light that undeniably makes us (as "we" are usually defined) - want to go.

And when I think along those lines, my mind goes to the question not only of the going but also of the gone. A sparkling city that prides itself on never sleeping (whether that is New York, Rio, Shanghai, London,
Paris, or any of the other candidates at hand) is a problem for winged things with a touch of phototropism.

The 20th century experience of sparkling cities that never sleep has perhaps (depending on what we mean by we) made us more comfortable in the 21st. But it has had disastrous consequences for those outside the circle of "we."

I find myself in Chicago between the sparkling city and the dispersed city of the plains (as Harris Stone called the middle of the United States), and I think I am in the middle of a single city, a city that has not stopped to think since the industrial revolution began (Stone 1998).

Now is as good a time as any.

Sparkling cities that do not sleep spawned expanding circles of suburbs intended to do nothing but. And they did this in tandem with super-States that flattened the world into a single global Market. The patch of grass we have flattened circling to make ourselves comfortable, it seems, is the entire planet.

Between the lines of Aristotle's discourses on natural slaves and barbarians, we can read an interesting argument that might be useful as we light on this particular perch. The circle of we that marks the tangible form of one city also draws what looks from here like an other: this and that, the city that sparkles and everything else. This matters; that is matter to be used and/or space to be occupied.

The impulse where I grew up is to get as far away from that bloody city as possible (going the other way, like Jonah, when Nineveh calls). What has slowly dawned on me after decades of living in between is that this is the same impulse that drives all those sleepy people from the sparkling city to widen the circles of their suburbs until all is sub to that sleepless urb. Jonah, by the way, is a good joke (and it was Dick Luecke who taught me this as well) because when the prophet runs away from the bloody city he finds himself treading water to avoid drowning in the ocean of it. Political animals we are. We can run but we can't hide. So the challenge - and this is a challenge for which vines withering where prophets go looking for shady places to watch bloody cities go up in smoke may mean something to architects interested in making good our stays in cities for which they are making plans.

So - six suggestions:

Make no little plans, as Daniel Burnham said, but keep in mind that even the big plans are little. It is all politics, and all politics is local.

You can run, but you cannot hide. If you are human, you live in the city.

Successful flight requires places to light. People will always fly from a city in which they cannot rest. 
There are no eternal cities, so there is no reason to try to build one. Because we are human, we live in the city. But because every city is human, every city will die.

This is no more the center of the universe than that. We are all squatters here, on the way from one there to another.

On the way, we are nomads. Our stopping places will always be places that do not belong to us where others will also pitch their tents. The city must be hospitable and accommodating, a party, yes, but also a sanctuary.

I have been writing under the influence of Aristotle, so I am acutely aware of the importance of posing the problem clearly and accurately. That small step is more than half the journey, and it is particularly important where symptoms threaten to overshadow the problem itself. In this case, the most glaring symptoms - evidence that there is a problem - are urban sprawl and deepening tension between urban and rural populations (marked in part by the movement of rural youth to urban centers, which effectively transforms them into raw material for urban expansion). One effect of the deepening tension is a sense of disempowerment that adds fuel to the fire. There is also an experience of fragmentation within individuals as well as between populations. In places like China, there is a growing instability (and - just as important - fear of instability) that has an immediate and lasting effect on the disposition of power. This may not be so obvious in the United States or Europe, but it is no less present. All of these symptoms have an urgency about them that prompts immediate and often repressive response. That, in turn, exacerbates the symptoms. Given the evidence of a problem afforded by the symptoms, the question is not (yet) what is to be done? The question (for now) is what is the problem?

The problem is not the existence of sparkling cities that do not sleep. It is not the existence of high density urban centers within the human experience of being in the world - within the city. It is the flattening of the world that follows from a particular way of centering power - a widening gyre that flattens everything in sight. New York sparkles; but when Santa Fe, New Mexico, or Marfa, Texas, begins to resemble a New York suburb, we are in danger of losing our soul - not because Marfa or Santa Fe is better than New York but because they are different. And in losing the difference we lose the form that gives shape to the whole. This is not new to those who have experienced the colonialism that has gone hand in hand with the emergence of mega-cities and super-States. And I think one salutary response for architects planning cities might be to look again at anti-colonialist theories from Franz Fanon to
Enrique Dussel. Dussel in particular makes a point of listening for voices from the other side (and we should bear in mind that every side is other to some other other) (Dussel 2003).

Practically, I think this points in two seemingly contradictory directions. First, it demands careful attention to the preservation of "outside" - not as theme park or wilderness but as a dimension of city, of human being in the world. And, second, it demands that this "outside" turn and invade the supposed center - not as theme park but as living presence.

Even the most ardent partisans of sparkling New York will allow that it is not one city. At the very least, it is five - as anyone who lives in Brooklyn, Queens, the Bronx, or Staten Island can tell you. The sparkling city that thinks itself center is Manhattan - and it has something to offer 21 st century city thinking.

The paradox of the invasion of the outside I suggested a moment ago is that it calls for greater density as a corrective to sprawl. The urban centers that result are likely to look more like Manhattan or Hong Kong than the linear cities characteristic of 20th century urban sprawl (for which Shenzhen could be the poster child). The challenge for architects, I think, is to knock the legs of necessary expansion for lebensraum out from under the global city and its development. That means mixed use zoning and development that makes it possible for people to stay rather than necessary for them to retreat from the place where they work during the two thirds of their time reserved for rest and what you will. Retreating has given the global city its shape, and the challenge is to reshape it around being here, not elsewhere.

Paradoxically, this requires mobility with minimal destructive impact - and that means reinventing transportation in an image other than the private automobile. That is not to be accomplished by dropping bicycle lanes on top of an urban grid determined by automobiles. It requires breaking the grid.

And that means, among other things, challenging the illusion of permanence while embracing the fact of more people in no more space - increasing density. If we are all nomads squatting in the material world, then the material design of shelter should make it more, not less, accessible to more, not fewer, people. Expanding public space as sanctuary right in the middle of urban concentration, reasserting the commons - not occupying it as a matter of ownership but being at home as stranger and guest.

When rich and powerful people occupy temporary shelter (hotel rooms, e.g.), a vast machinery is put into play to make them feel at home. What sort of machinery might make that happen in temporary public 
spaces? And what if we considered "temporary" and "public" to be the norm for spaces in which humanity takes place?

If you see something say something, I hear them say every time I take a train. Every time I take a train, I see something else. And seeing something even when I am looking for nothing, I am pleased to imagine saying nothing a subversive act. Nothing will ever be the same, and that may be the stasis around which a res publica can circle without making the whole world flat. Pitching a tent, not erecting a temple, we make a scene - and when we leave, it is as though we were never there.

No abstract outside the world squatting being - but being concrete squatting in the world, flying, lighting now and then on a sparkling city, still turning toward good, turning.

\section{References}

Aristotle. 1932. Politics. Loeb Classical Library 264. Translated by H. Rackham. Harvard University Press.

Dussel, E. 2003. Philosophy of liberation. Translated by A. Martínez and M. Morkovsky. Wipf \& Stock.

Goethe, J. 1997. Faust. Könemann.

James, W. 1918. Principles of psychology. Dover.

Luecke, R. 1972. Perchings: reflections on society and ministry. Fortress.

Marx, K. 2007. Zur Kritik der Hegelschen Rechtsphilosophie. Einleitung (1844), in Der junge Marx: philosophische Schriften. Edition linke Klassiker. Ed. by Kraft, S. and Reitter, S. K. K. Promedia Verlag, 109-120.

Smith, A. 1976. An inquiry into the nature and causes of the wealth of nations. Ed. by E. Cannan. University of Chicago Press.

Stevens, W. 2011. Description without place, in The collected poems of Wallace Stevens. Random House.

Stone, H. 1998. Dispersed city of the plains. Monthly Review Press.

Taussig, M. 1993. Mimesis and alterity: a particular history of the senses. Psychology Press.

Williams, M. 1999. Politics, in Some jazz a while: collected poems. University of Illinois Press.

\section{STEVEN SCHROEDER}

Graham School of Continuing Liberal and Professional Studies, University of Chicago, Chicago, USA.

E-mail: schroeder@uchicago.edu

Steven Schroeder is a poet, philosopher and visual artist who lives and works in Chicago. He obtained his Ph.D from the University of Chicago in Ethics and Society and is an author of numerous books, including On Not Founding Rome, Between Freedom and Necessity, The Metaphysics of Cooperation. Steven's most recent poetry collections are Raging for the Exit (with David Breeden) and We're Open, Come In. More at stevenschroeder.org. 